\title{
In vitro multiplication of pear tree cultivar Cascatense
}

\section{Multiplicação in vitro de pereira cultivar Cascatense}

\author{
Ilda Mariclei de Castro da Silva ${ }^{1 *}$; Cristina Copstein Cuchiara ${ }^{1}$; \\ Mara Cíntia Winhelmann²; Valmor João Bianchi³; Eugenia Jacira Bolacel Braga ${ }^{4}$; \\ Leonardo Ferreira Dutra ${ }^{5}$ José Antonio Peters ${ }^{3}$
}

\begin{abstract}
One main obstacle to the development and expansion of pear tree cultivation in Brazil has been the lack of cultivars adapted to the edaphoclimatic conditions of regions with the potential for pear production. Intending to overcome this hindrance, Embrapa Clima Temperado (Embrapa Temperate Climate) developed and released the cultivar Cascatense, with a low cold requirement ( $\sim 400 \mathrm{~h})$ better suited for Rio Grande do Sul's and Santa Catarina`s climate. Still, seedlings of high genetic and sanitary quality are necessary for the establishment of a high-yield orchard. Plants with both sanitary quality and uniformity can be obtained through in vitro micropropagation. Thus, the present study aimed to assess the influence of different culture media (MS, MS $3 / 4$, WPM, QL, and Himédia), concentrations of sucrose $\left(0,15,30,45\right.$, and $\left.60 \mathrm{~g} \mathrm{~L}^{-1}\right)$, and concentrations of benzylaminopurine (BAP) $(0,0.4,0.8,1.2$, and 1.6 $\mathrm{mg} \mathrm{L}^{-1}$ ) upon the in vitro multiplication of cultivar Cascatense, to establish an efficient protocol to enhance its propagation and reproducibility. The study included three sequential experiments in which the number of shoots per explant, the length of shoots, the number of axillary buds per shoot, fresh mass, and dry mass of shoots were evaluated. Cultivar Cascatense can be best propagated in vitro with the use of Himédia medium, supplemented with $0.8 \mathrm{mg} \mathrm{L}^{-1}$ of BAP and $30 \mathrm{~g} \mathrm{~L}^{-1}$ of sucrose.
\end{abstract}

Key words: Himédia medium. Ferrous sulfate. Ferric sulfate. Sucrose. Benzylaminopurine.

\section{Resumo}

Um dos principais entraves ao desenvolvimento e expansão da cultura da pereira no Brasil tem sido a falta de cultivares adaptadas às condições edafoclimáticas das regiões potencialmente produtoras. Visando sanar esta dificuldade, a Embrapa Clima Temperado desenvolveu e lançou a cv. Cascatense, com baixa exigência em frio ( $\sim 400 \mathrm{~h})$, mais adequada ao clima do Rio Grande do Sul e de Santa Catarina. No entanto, mudas com alta qualidade genética e sanitária são necessárias para garantir a boa formação de um pomar produtivo. Plantas com qualidade sanitária e uniformidade podem ser obtidas através da micropropagação in vitro. Assim, o presente trabalho teve como objetivo verificar a influência de diferentes meios de cultivo (MS, MS³/4, WPM, QL e Himédia), concentrações de sacarose $(0,15,30$, 45 e $\left.60 \mathrm{~g} \mathrm{~L}^{-1}\right)$ e benzilaminopurina - BAP $\left(0 ; 0,4 ; 0,8 ; 1,2\right.$ e $\left.1,6 \mathrm{mg} \mathrm{L}^{-1}\right)$ na multiplicação in vitro da cv. Cascatense, visando obter um protocolo eficiente para potencializar sua propagação e reprodutibilidade. Os estudos foram conduzidos em três experimentos sequenciais, nos quais foram avaliados o número de brotações por explante, o comprimento das brotações, o número de gemas axilares por brotação, massa fresca e massa seca das brotações. A cv. Cascatense pode ser propagada in vitro com a utilização do meio Himédia suplementado com $0,8 \mathrm{mg} \mathrm{L}^{-1}$ de BAP e $30 \mathrm{~g} \mathrm{~L}^{-1}$ de sacarose.

Palavras-chave: Meio himédia. Sulfato ferroso. Sulfato férrico. Sacarose. Benzilaminopurina.

${ }^{1}$ Biólogas, Dras em Fisiologia Vegetal, Dept ${ }^{\circ}$ de Botânica, DB, Instituto de Biologia, IB, Universidade Federal de Pelotas, UFPel, Capão do Leão, RS, Brasil. E-mail: ildamcastro@hotmail.com; cccuchiara@hotmail.com

2 Discente do Curso de Graduação em Agronomia, Faculdade de Agronomia Eliseu Maciel, FAEM, UFPel, Capão do Leão, RS, Brasil. E-mail: marawinhelmann@yahoo.com.br

${ }^{3}$ Eng ${ }^{\text {os }}$ Agros , Profs. Drs., DB, IB, UFPel, Capão do Leão, RS, Brasil. E-mail: valmorjb@yahoo.com; japeters1@hotmail.com

${ }^{4}$ Bióloga, Prof ${ }^{a}$ Dra, DB, IB, UFPel, Capão do Leão, RS, Brasil. E-mail: jacirabraga@hotmail.com

5 Pesquisador, Laboratório de Cultura de Tecidos, LCT, Empresa Brasileira de Pesquisa Agropecuária, Embrapa Clima Temperado, Pelotas, RS, Brasil. E-mail: leonardo.dutra@embrapa.br

* Author for correspondence 


\section{Introduction}

Because pears (Pyrus sp.) are a highly acceptable fruit for in natura consumption, their production and consumption is important worldwide (FAO, 2012). In Brazil, pears are the third most-consumed, temperate-climate fruit; however, they are also the most heavily imported fresh fruit (approximately $200,000 \mathrm{t} \mathrm{year}^{-1}$, corresponding to $90 \%$ of the country's total consumption), because the low yield and small amount of cultivated area meets only $10 \%$ of the home market demand (FACHINELLO et al., 2011).

One of the chief obstacles to the development and expansion of the crop has been the shortage of cultivars adapted to the edaphoclimatic conditions of potential regions for production (NAKASU; LEITE, 1992). Rio Grande do Sul and Santa Catarina are the states with the most favorable climatic conditions for pear production (ABF, 2013). However, in many places, and in certain years, the number of hours of hibernal cold is insufficient for good, uniform shooting and blossoming of any of the main species that have been introduced into Brazil, including those of European origin, Asian pear trees (Nashis), and other hybrids.

Cultivar Cascatense, initially named 'Pirus 9', was developed by Embrapa Clima Temperado (Embrapa Temperate Climate) from the cross of 'Packham's Triumph' with 'Le Conte', and released in 1992. It has a low cold requirement and produces good quality fruit that are piriform and medium-sized. The plant's presentation is vigor medium to semi-vigorous, semi-opened, and highly yielding, with earlier and more uniform shooting. Its hibernal cold requirement is approximately 400 $\mathrm{h}$ (temperature $\leq 7.2^{\circ} \mathrm{C}$ ), a condition that is present most years in the regions of Rio Grande do Sul and Santa Catarina that produce other temperate climate fruits (NAKASU; LEITE, 1992).

In Brazil, pear seedlings are normally propagated using cleft grafting methods on rootstocks of pear or quince trees (FELDBERG et al., 2010), or by cutting through the self-rooting portion of the scion cultivar (GIACOBBO et al., 2007). According to Jartoodeh et al. (2013), these methods can present problems due to grafting incompatibility and the poor rooting potential of the scion cultivar, respectively. Additionally, according to Wood (1997), such methods of woody plant propagation can significantly contribute to the dissemination of various plant pathogens, including fungi, bacteria, phytoplasmas, and viruses. Such pathogens negatively affect plant development, orchard yield, and fruit quality. Therefore, propagation techniques and the sanitary quality of the materials utilized warrants special attention.

When the production of seedlings with high sanitary quality and uniformity is desired, propagation of the plant material can be accomplished through micropropagation or in vitro propagation (YASEEN et al., 2009a, 2009b; BANDEIRA et al., 2012; ASGHARI et al., 2013). The primary advantage of this biotechnological method is the production of a high number of plants in a short period (CARVALHO et al., 2011).

Micropropagation protocols have been developed to optimize the in vitro culture conditions for high multiplication rates, both in pear trees (BOMMINENI et al., 2001; BELL; REED, 2002; HASSANEN; GABR, 2012; KARIMPOUR et al., 2013) and in other Rosaceae (YASEEN et al., 2009b; SILVA et al., 2011; VUJOVIC et al., 2012). For adequate growth and development to occur during the multiplication phase, it is necessary to control morphogenesis, a process influenced by several factors such as species, cultivar, type of explant, components of the nutrient medium, growth regulators added to the culture medium, and environment (BELL et al., 2009; SILVA et al., 2011).

In the in vitro multiplication of woody plants, buds or shoot tips are normally employed (BELL; REED, 2002; BELL et al., 2009; HASSANEN; GABR, 2012; KARIMPOUR et al., 2013). The 
culture media may be either liquid or semisolid, and is made up of mineral salts (macro and micronutrients), carbohydrates, vitamins, and growth regulators (D'ONOFRIO; MORINI, 2005; CIELNIAK et al., 2008; SILVA et al., 2011). There are a number of different culture media, each with differing salt and vitamin concentrations according to the needs of the species or cultivar. Media are made into gel with different agents (RODRIGUEZ et al., 1991; BELL; REED, 2002; LUCYSZYN et al., 2006; BELL et al., 2009), but the most utilized are MS (MURASHIGE; SKOOG, 1962) and its modifications and dilutions, as well as WPM (Wood Plant Medium) (LLOYD; McCOWN, 1980), QL (QUOIRIN; LEPOIVRE, 1977), and DKW (DRIVER; KUNIYUKI, 1984), the formulations of which are considered most diluted.

The concentration of carbon in the culture medium, and the particular source of carbon, are other important factors during multiplication of the explants. Carbohydrates supply energy and contribute towards the equilibrium of the medium's osmotic potential (KADOTA; NIIMI, 2003; PATI et al., 2006). In general, the preferred carbon source is sucrose at $3 \%$ concentration, because it is the predominant carbohydrate in the phloem sap of the majority of plants and has a lower cost than many alternatives (YASEEN et al., 2009b).

Growth regulators are also important. During pear tree multiplication, the source and kind of cytokinin utilized influences the induction and proliferation of axillary buds (HASSANEN; GABR, 2012; KARIMPOUR et al., 2013). Among cytokinins, 6-benzylaminopurine (BAP), is lower cost than many alternatives and is the most utilized for inducing cell division and shoot development (LUCYSZYN et al., 2006; RUZIC et al., 2008; HASSANEN; GABR, 2012).

The purpose of this study was to investigate the influences of different culture media and different concentrations of sucrose and BAP upon the in vitro multiplication of the cultivar Cascatense, to establish an efficient protocol to bolster its propagation/reproducibility.

\section{Material and Methods}

The explants utilized for this investigation were cuttings obtained from pear tree shoots (Pyrus sp.), cultivar Cascatense, each with two to three axillary buds. Explants were pre-established in vitro, in the culture medium MS Himédia ${ }^{\circledR}$ (a commercial medium with a formulation equal to $\mathrm{MS}$ ) with 0.8 mg L ${ }^{-1}$ BAP, $30 \mathrm{~g} \mathrm{~L}^{-1}$ sucrose, and $7 \mathrm{~g} \mathrm{~L}^{-1}$ agar. The $\mathrm{pH}$ was adjusted to 5.8. The study was conducted in three sequential experiments, with each experiment repeated twice. Nodal segments of approximately $1.0 \mathrm{~cm}$, containing from two to three axillary buds, were utilized as initial explants.

\section{Experiment 1 - Different culture media}

The explants were cultivated in five different media: full-strength MS, MS $3 / 4$ (containing $3 / 4$ of the normal concentrations of $\mathrm{NH}_{4} \mathrm{NO}_{3}$ and $\mathrm{KNO}_{3}$ ), $\mathrm{MS}$ Himédia, WPM, and QL, with $0.8 \mathrm{mg} \mathrm{L}^{-1} \mathrm{BAP}, 100$ $\mathrm{mg} \mathrm{L}{ }^{-1}$ myo-inositol, $30 \mathrm{~g} \mathrm{~L}^{-1}$ sucrose, and $7 \mathrm{~g} \mathrm{~L}^{-1}$ agar added to each. All media were adjusted to a $\mathrm{pH}$ of 5.8. Full-strength MS, MS $3 / 4$, and QL were prepared with ferric-EDTA, but MS Himédia and WPM were prepared with ferrous-EDTA, according to the original formulation of the MS medium.

For 40 days, the flasks were maintained in a growth chamber at a temperature of $23 \pm 2^{\circ} \mathrm{C}$, with a 16-hour photoperiod and $48 \mu \mathrm{mol} \mathrm{m} \mathrm{m}^{-2} \mathrm{~s}^{-1}$ of photon flux. After this period, the number of shoots per explant, the length of the shoots $(\mathrm{cm})$, and the number of axillary buds per shoot was measured. Fresh mass of the shoot and dry mass ( $g$ ) were also measured, with the material dried in a forced ventilation oven at $\pm 50{ }^{\circ} \mathrm{C}$ to constant mass. 


\section{$\begin{array}{lcc}\text { Experiment } \quad 2 & - \\ \text { 6-benzylaminopurine }(B A P)\end{array}$}

This experiment utilized the MS Himédia culture medium, $\mathrm{pH} 5.8$, supplemented with varying concentrations of $\operatorname{BAP}(0,0.4,0.8,1.2$, and $1.6 \mathrm{mg}$ $\left.\mathrm{L}^{-1}\right), 30 \mathrm{~g} \mathrm{~L}^{-1}$ sucrose, and $7 \mathrm{~g} \mathrm{~L}^{-1}$ agar. MS Himédia was chosen for this experiment because it presented the best results in Experiment 1. Growing conditions and variables for this experiment were the same as those described for Experiment 1.

\section{Experiment 3 -Sucrose concentration}

Growing conditions and variables surveyed were the same as described for the preceding experiments. The medium used was Himédia, $\mathrm{pH}$ 5.8, with 0.8 $\mathrm{mg} \mathrm{L}^{-1} \mathrm{BAP}$, varying concentrations of sucrose $(0$, $15,30,45$, and $60 \mathrm{~g} \mathrm{~L}^{-1}$ ), and $7 \mathrm{~g} \mathrm{~L}^{-1}$ of agar.

\section{Experimental design and statistical analysis}

For all experiments, a randomized design was used. There were nine replicates per treatment, each consisting of a flask containing five explants. For evaluation of fresh mass and dry mass of the shoots, five replicates were selected randomly. From each of those, three plants were randomly selected for a total of 15 plants per treatment evaluated for mass.

The treatments were compared as follows: culture medium (MS, MS $3 / 4$, MS Himédia, WPM, and QL) in Experiment 1, BAP concentration (0, $0.4,0.8,1.2$, and $\left.1.6 \mathrm{mg} \mathrm{L}^{-1}\right)$ in Experiment 2, and sucrose concentration $\left(0,15,30,45\right.$, and $\left.60 \mathrm{~g} \mathrm{~L}^{-1}\right)$ in Experiment 3. Variance analysis was performed, and when differences in the data were significant, the means were either compared by the Tukey test at a level of 5\% probability of error or surveyed by polynomial regression utilizing the software WINSTAT 1.0 (MACHADO; CONCEIÇÃO, 2007). The maxima points were calculated by the formulas $\mathrm{x}=-\mathrm{b} / 2 \mathrm{c} \mathrm{e}, \mathrm{y}=$

$$
-\left(-b^{2}-4 a c\right) / 4 c \text {. }
$$

of Results

\section{Experiment 1 - Effect of different culture media}

When different culture media were evaluated, the greatest average number of shoots per explant (6.18) was found in the medium WPM (Figure 1A). However, the greatest values for length $(2.5 \mathrm{~cm})$, fresh mass $(0.39 \mathrm{~g})$, dry mass of shoots $(0.06 \mathrm{~g})$, and number of axillary buds per shoot (13.17) were obtained in the Himédia medium (Figures 1B, C, $\mathrm{D}$, and $\mathrm{E}$ ). For the last variable, number of axillary buds per shoot, Himédia did not significantly differ from MS media (12.1) and $\mathrm{MS}_{3}^{3} / 4$ media (11.83). In addition, there was no marked difference in the dry mass of shoots from Himédia as compared to shoots from WPM. The QL culture medium was not evaluated for the number of axillary buds/ shoot, because the reduced size of the formed shoots (shorter than three millimeters) did not allow adequate counting.

\section{Experiment 2- Effects of the concentration of} 6-benzylaminopurine (BAP)

The addition of BAP to the culture medium resulted in a quadratic response for several variables including length and number of shoots per explant, as well as fresh and dry mass of shoots. For the number of shoots per explant and length of shoots, the maxima point for length occurred in concentrations of 1.02 and $1.26 \mathrm{mg} \mathrm{L}^{-1}$ of BAP at 4.95 and $2.28 \mathrm{~cm}$ in length, respectively. However, the greatest number of shoots per explant (5.2) was obtained at a concentration of $0.8 \mathrm{mg} \mathrm{L}^{-1}$ for the growth regulator (BAP) (Figure 2A), with the greatest length of those $(2.35 \mathrm{~cm})$ recorded at the highest concentration tested $\left(1.6 \mathrm{mg} \mathrm{L}^{-1}\right)$. This result was not much better than that found when the concentration of $0.8 \mathrm{mg} \mathrm{L}^{-1}$ of BAP $(2.09 \mathrm{~cm})$ was utilized (Figure 2B). 
Figure 1. Average number of shoots per explant (A), length of the shoots (B), number of axillary buds per shoot (C), fresh and dry mass of the shoots (D and E) of pear tree, cultivar Cascatense with regard to different culture media. $* *$ Significant by $\mathrm{F}$ test at $1 \%$ probability of error. Means followed by the same capital letter do not differ from one another in results of the Tukey test at $5 \%$ of probability of error.
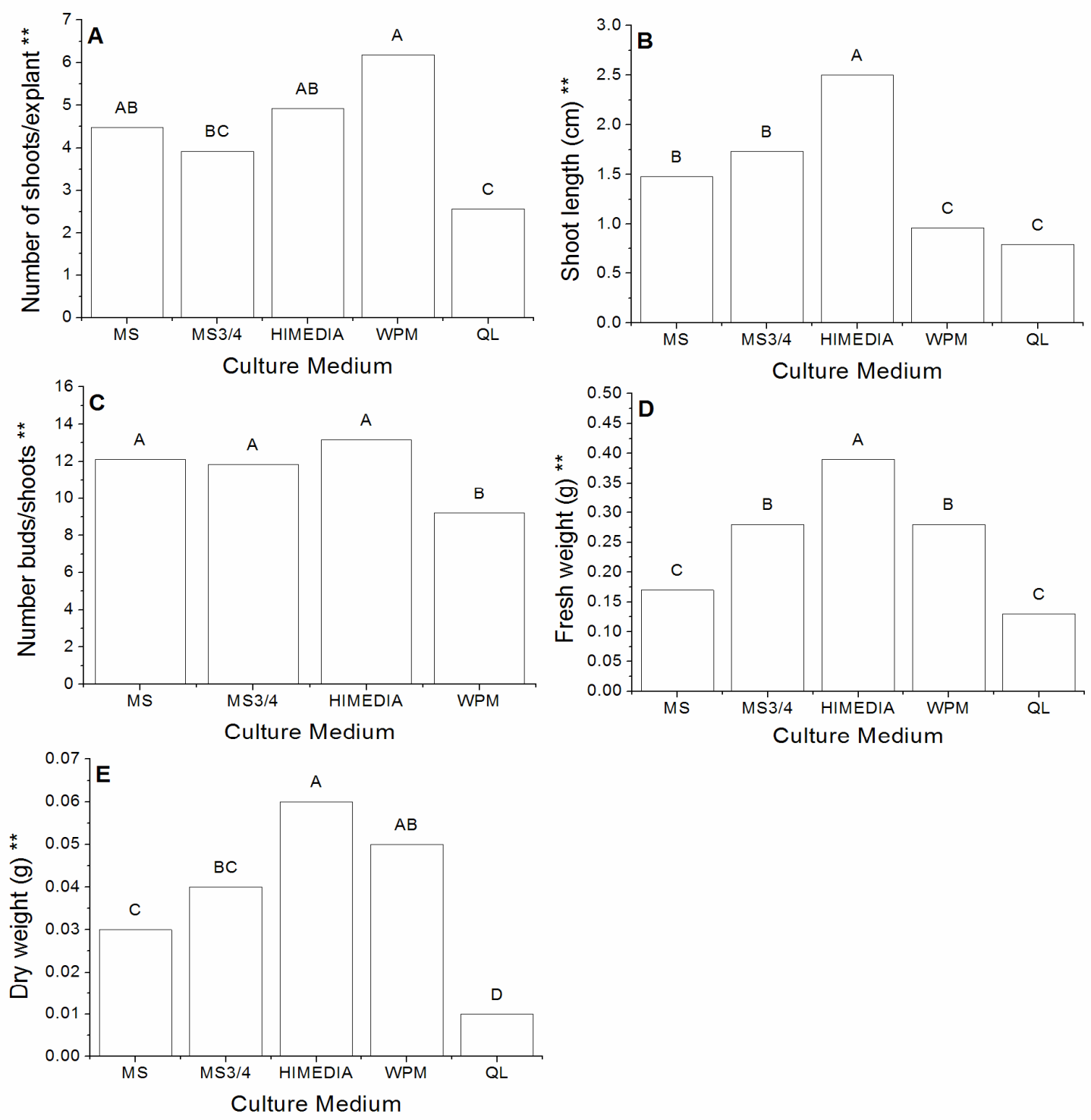
Figure 2. Average number of shoots per explant (A), length of the shoots (B), number of axillary buds per shoot (C), fresh and dry mass of the shoots (D and $\mathrm{E}$ ) of pear tree, cultivar Cascatense, obtained under different concentrations of BAP $\left(\mathrm{mg} \mathrm{L}^{-1}\right)$ in MS Himédia medium **Significant by $\mathrm{F}$ test at $1 \%$ probability of error.
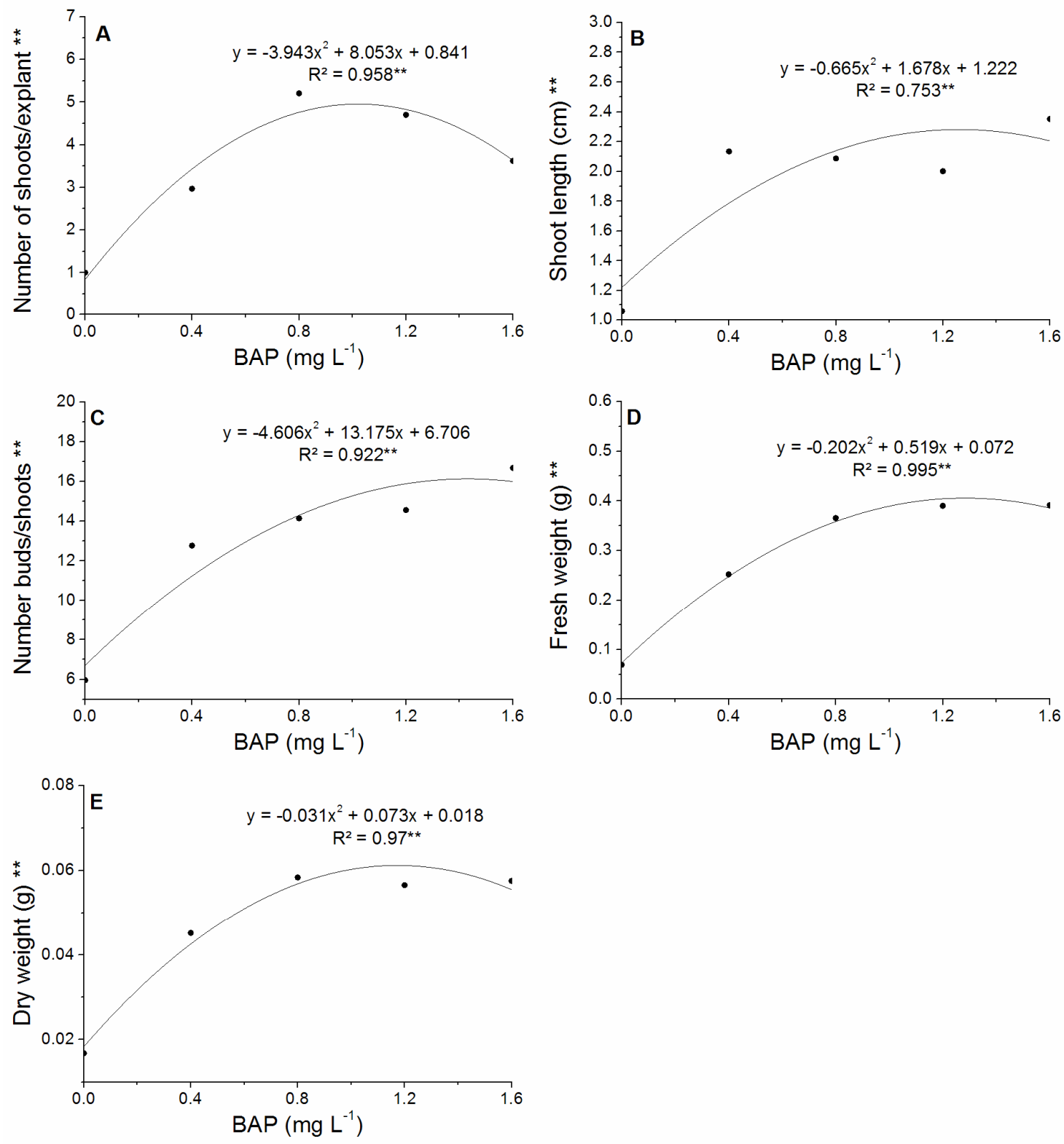

For fresh and dry mass, the estimate of the regression equation showed that the greatest values (0.4 and $0.06 \mathrm{~g}$ ) occurred at concentrations of 1.28 and $1.18 \mathrm{mg} \mathrm{L}^{-1}$ of BAP, respectively (Figure 2D and $2 \mathrm{E})$. The increased concentration of BAP from 0.8 $\mathrm{mg} \mathrm{L}^{-1}$ on did not determine increments in the dry mass of the shoots. Axillary buds per shoot showed a growing linear response with greater values

obtained at the $1.6 \mathrm{mg} \mathrm{L}^{-1}$ concentration (Figure $2 \mathrm{C}$ ), presenting a mean of 16.68 formed buds.

\section{Experiment 3 - Effects of sucrose concentration}

Addition of sucrose to the culture medium produced a quadratic response trend in all surveyed variables. The highest estimated values for number 
of shoots per explant (4.95) and length of shoots $(2.06 \mathrm{~cm})$ occurred at concentrations of 32.13 and $29.0 \mathrm{~g} \mathrm{~L}^{-1}$ of sucrose, respectively. However, numerically it was found that the use of $30 \mathrm{~g} \mathrm{~L}^{-1}$ of this carbohydrate induced the best responses, with formation of 5.1 shoots per explant (Figure 3A) and a mean of $2.2 \mathrm{~cm}$ in length (Figure 3B).

Figure 3. Average number of shoots per explant (A), length of the shoots (B), number of axillary buds per shoot (C), fresh and dry mass of the shoots (D and E) of pear tree, cultivar Cascatense obtained in MS Himédia medium containing different sucrose concentrations. ${ }^{* *}$ Significant by $\mathrm{F}$ test at $1 \%$ probability of error.
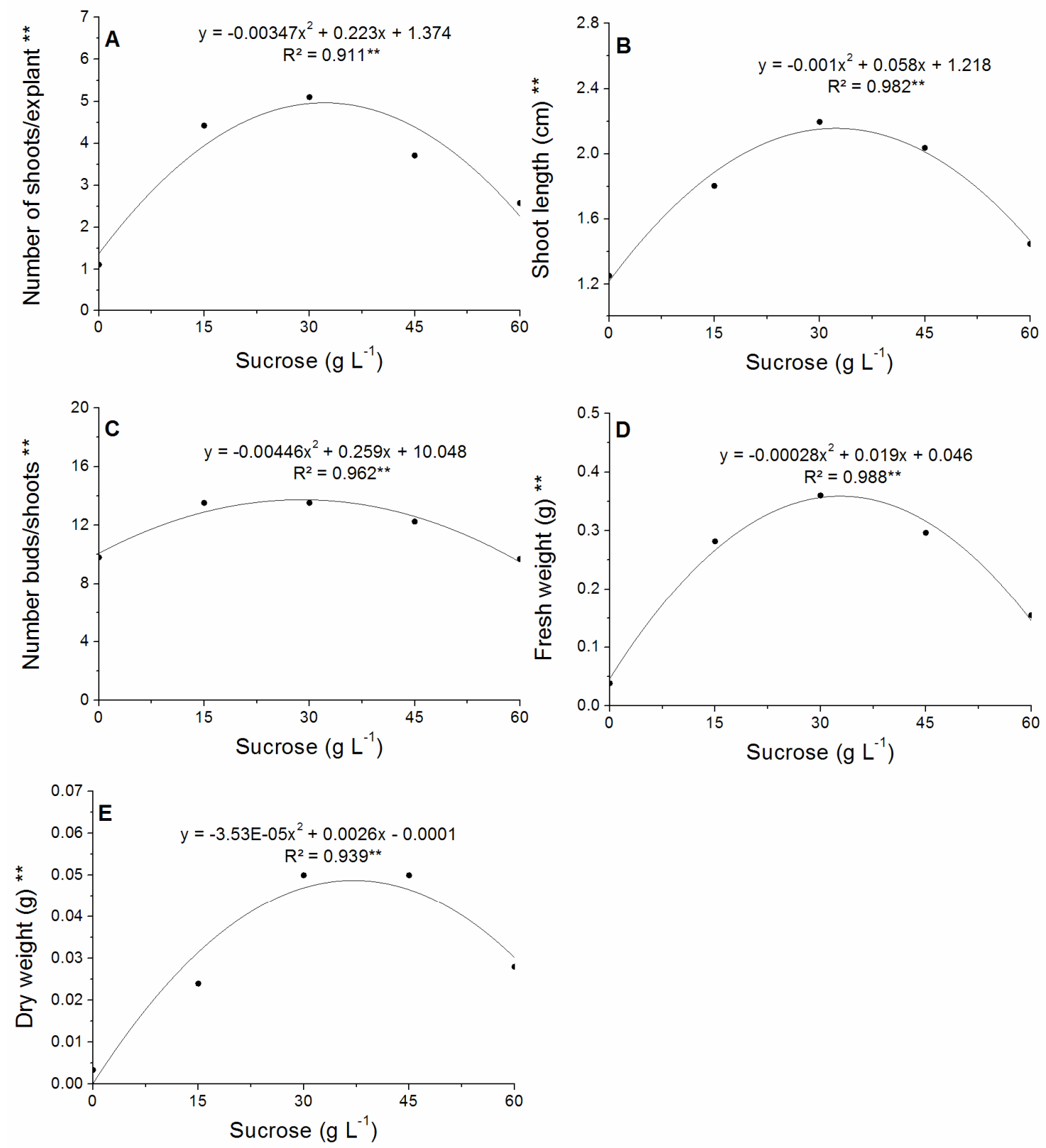
According to the regression equation, higher estimated values for the number of axillary buds per shoot (13.80) (Figure 3C) and fresh mass (0.36 g) (Figure 3D) were obtained at concentrations of 29.03 and $33.93 \mathrm{~g} \mathrm{~L}^{-1}$ of sucrose, respectively. However, these values were not much higher than those obtained with a concentration of $30 \mathrm{~g} \mathrm{~L}^{-1}$ of sucrose, which produced 13.52 formed axillary buds and $0.36 \mathrm{~g}$ fresh mass.

For dry mass, although the maxima point indicates that the ideal concentration would be $36.83 \mathrm{~g} \mathrm{~L}^{-1}$ of sucrose, producing of $0.048 \mathrm{~g}$ (Figure $3 \mathrm{E})$, absolute values showed that the means were higher when supplemented with both 30 and $45 \mathrm{~g}$ $\mathrm{L}^{-1}$ of this sugar in the culture medium $(0.05 \mathrm{~g})$.

\section{Discussion}

Growth rates and development of shoots/ plants grown in vitro are genetically determined. However, they are limited by factors of the physical and chemical microenvironment in the growing containers, such as concentrations of nutrients and growth regulators that can endanger the formation of shoots and/or microplants (BOMMINENI et al., 2001; BELL; REED, 2002; CASANOVA et al., 2008). Consequently, the quantity and balance of growth regulators, carbohydrates, and other nutrients are determining factors in the success of in vitro multiplication of plant material (BELL; REED, 2002; RUZIC et al., 2008; MORAES et al., 2004; DOBRÁNSZKI; TEIXEIRA DA SILVA, 2010), as demonstrated by the results in this study.

Due to the important role minerals play in growth and regulation of morphogenesis, the constitution of each culture medium should be based on a plant's requirements for mineral nutrients that meet specific needs (RODRIGUEZ et al., 1991; BELL et al., 2009; HASSANEN; GABR, 2012). A plant's supply, absorption, transport, and metabolism appear to vary between the stages of development of the organs, initiation of meristems, and during growth (RAMAGE; WILLIAMS, 2002). Through examination of the influence of different culture media and salt concentrations during multiplication of the cultivar in this study (Figure 2A), it was found that, in general, MS Himédia produced the best results. Because this is an already-prepared medium from an internationally renowned company, the positive growth response may relate to the quality of the minerals used and the automated preparation in a commercial environment as compared to preparation in a laboratory, as was the case for the other media, where further variation occurs in the makes and quantities of the reagents used.

Another aspect to consider is that both MS Himédia and WPM were prepared with iron in the reduced form (EDTA-Ferrous), while the fullstrength $\mathrm{MS}, \mathrm{MS}^{3} / 4$, and QL were prepared with iron in the form of oxidized ferric-EDTA. According to Schmidt (2003), iron is a micronutrient essential for plant growth and development, and is involved in various processes such as mitochondrial respiration and photosynthesis. For most plants, iron is preferentially absorbed in the $\mathrm{Fe}^{2+}$ form, although it may also be absorbed as $\mathrm{Fe}^{3+}$-chelate and to a lesser extent as $\mathrm{Fe}^{3+}$ (KOBAYASHI; NISHIZAWA, 2012). These changes could be responsible for the increased number of shoots per explant when using WPM. However, at the same time, the shoots were of a shorter length. This contradictory behavior is explained by the fact that the exacerbated increase in the number of shoots would have promoted competition for the salts and vitamins in the culture medium, thus reducing growth (OLIVEIRA et al., 2001).

For plants in the QL medium, a reduction was observed for all studied variables, and the number of buds per shoot could not be assessed. These results can be explained by the fact that this medium contains only $25 \%$ of the nitrogen concentration $\left(\mathrm{NH}_{4} \mathrm{NO}_{3}\right)$ present in MS, demonstrating that very dilute compositions of this macronutrient are not favorable to the multiplication of the cultivar Cascatense. Nitrogen is one of the major essential nutrients, absorbed mainly in the form of nitrate 
$\left(\mathrm{NO}_{3}^{-}\right)$and ammonium $\left(\mathrm{NH}_{4}^{+}\right)$, and is a constituent of several essential biomolecules such as amino acids, nucleic acids, proteins, and enzymes. Owing to this, it has different effects on growth, vigor, and biomass production (XU et al., 2012).

Effects of different culture media and salt concentrations have been examined in several studies. WPM was developed for growing woody plants (LLOYD; McCOWN, 1980) and presents positive results in the micropropagation of species such as blueberry (SILVA et al., 2006) and Prunus sp. (RADMANN et al., 2009). MS is still the most used medium for the in vitro culture of Pyrus spp. (HASSANEN; GABR, 2012; KARIMPOUR et al., 2013). Therefore, in the absence of MS Himédia, we would recommend MS for the cultivar Cascatense, even with dilutions in the concentrations of $\mathrm{NH}_{4} \mathrm{NO}_{3}$ and $\mathrm{KNO}_{3}$, as can be viewed in Figure 4A.

Figure 4. Shoots of Pyrus sp., cultivar Cascatense, developed under different culture means (A), concentrations of BAP (B) and sucrose (C).

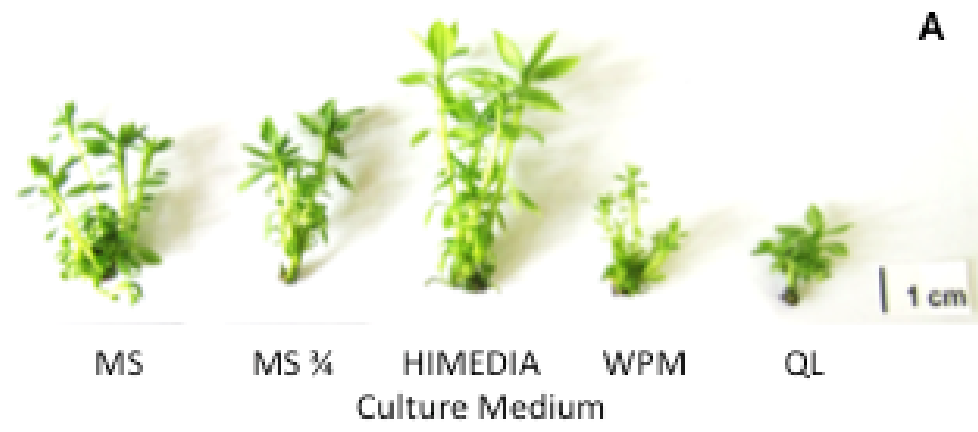

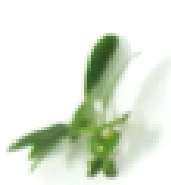

$0 \mathrm{mg} \mathrm{L}^{-1}$

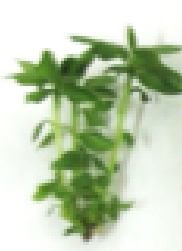

$0.4 \mathrm{mg} \mathrm{L}^{-1}$

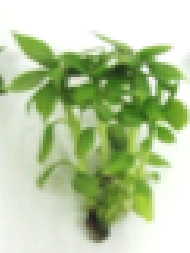

$0.8 \mathrm{mg} \mathrm{L}^{-1}$ BAP (mg L-1)

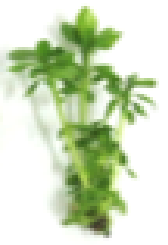

$1.2 \mathrm{mg} \mathrm{L}^{-1}$

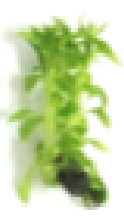

B

C

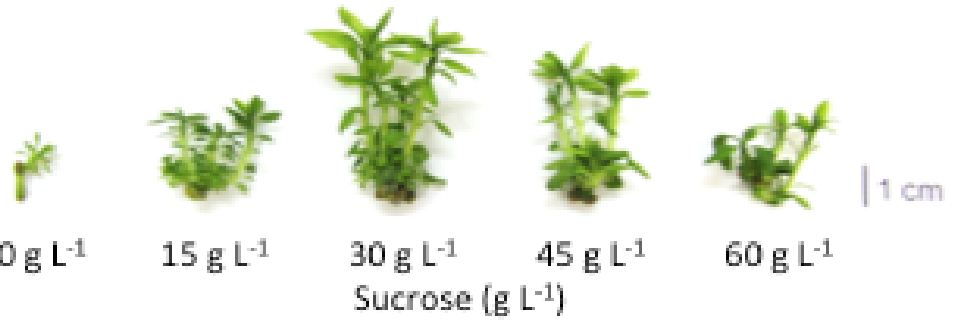


The results regarding use of different concentrations of BAP in the culture medium (Figure 4B) demonstrate that this growth regulator is indispensable in the in vitro multiplication phase of the pear tree cultivar Cascatense, consistent with observations made of other Pyrus spp. (RODRIGUEZ et al., 1991; HASSANEN; GABR, 2012; KARIMPOUR et al., 2013). BAP is responsible for cell division, overcoming apical dominance, and induction of the proliferation of axillary buds (MOK et al., 2000). The present results are similar to those observed by Moraes et al. (2004) in Pyrus calleryana D-6 and Radmann et al. (2011) in the rootstock 'Flordaguard' (Prunus persica L. Bastch). Both studies found that in the absence of BAP, the emission of new shoots does not take place, creating a dependency on the addition of exogenous cytokinin for the induction of shoots in these two Rosaceae species.

According to Dantas et al. (2002) for in vitro multiplication to be considered efficient, it is necessary to obtain a satisfactory average rate of shoots in which quality and homogeneity are prioritized, as this contributes toward the success of the rooting phase, and subsequently, toward seedling production. According to the results observed in this study, because it is important to obtain shoots of an appropriate length to facilitate handling, separation, and later use in rooting, $0.8 \mathrm{mg} \mathrm{L}^{-1}$ of BAP was the concentration that provided the best results for in vitro propagation of cultivar Cascatense.

Although, the addition of a cytokinin stimulates shoot production, it is found that the needs of each genotype of Pyrus spp. are too diverse to obtain appropriate multiplication rates (RODRIGUEZ et al., 1991; BOMMINENI et al., 2001; HASSANEN; GABR, 2012; KARIMPOUR et al., 2013). Excess cytokinin is toxic, reduces crop development, and can lead to hyperhydricity (RAMAGE; WILLIAMS, 2002), which according to Hazarika (2006), is an event that may occur in tissue culture, generating physiological and morphological abnormalities in the plant tissue and affecting the processes of photosynthesis and gas exchange. The vitrified explants are characterized by having translucent, turgid, stiff leaves with a soaked aspect; being easily breakable; and having malformed and elongated shoots. This was confirmed in this study by plants grown in the highest concentration of BAP (1.6 $\left.\mathrm{mg} \mathrm{L}^{-1}\right)$ (Figure 4B).

Carbohydrates have a clear function in the growth medium as an energy source. They influence cell division rate, or degree of morphogenesis of the cells of the explants, and they also regulate the osmotic potential of the culture medium and thus, water and nutrient uptake by the plant cells (YASEEN et al., 2009b; DOBRÁNSZKI; TEIXEIRA DA SILVA, 2010). The concentration of carbohydrates in the culture medium is one of the parameters that is manifested by the growth/development of shoots. It presents correlations with the rooting ability of shoots because the initiation and growth of roots are energy-demanding processes (YASEEN, 2009a). However, excess carbohydrates can be harmful by inhibiting chlorophyll synthesis, and thus, reducing the photosynthetic capabilities of the crops (HAZARIKA, 2006).

In in vitro multiplication of the pear tree 'Cascatense', it was found that $30 \mathrm{~g} \mathrm{~L}^{-1}$ sucrose was the most effective concentration, and that higher or lower concentrations resulted in reduced growth and development of shoots, as can be viewed in Figure $4 \mathrm{C}$. Although, $3 \%$ is the most widely used in vitro concentration of sucrose for most species including Pyrus spp. (BOMMINENI et al., 2001; BELL et al., 2009; HASSANEN; GABR, 2012; VUJOVIC et al., 2012; KARIMPOUR et al., 2013), evaluating the appropriate concentration for each species/cultivar is of paramount importance due to its regulatory function in many vital plant processes. According to De Riek et al. (1997), $75 \%$ to $85 \%$ of the increase in biomass is due to carbon incorporation from sucrose added to the culture medium.

Success in establishing a proper protocol for large-scale plant propagation is closely related to the high multiplication rates of the explants. The 
parameters evaluated over these experiments serve as useful tools for checking these rates. However, the most important variables are the number and length of shoots, as well as the number of axillary buds per shoot. These variables jointly determine efficiency of the multiplication process, and further, as suggested by Radmann et al. (2009), the growth of shoots formed during the multiplication phase is a determining variable in the quality of the material for the rooting phase. In the present work, it was possible to identify the conditions suitable for in vitro multiplication of pear cultivar Cascatense using the commercial MS Himédia medium.

\section{Conclusion}

Under the conditions of this study, the most efficient protocol for in vitro multiplication, one of the micropropagation phases of cultivar Cascatense, is use of commercial MS Himédia, supplemented with $0.8 \mathrm{mg} \mathrm{L}^{-1}$ of BAP and $30 \mathrm{~g} \mathrm{~L}^{-1}$ of sucrose.

\section{References}

ANUÁRIO BRASILEIRO DA FRUTICULTURA ABF. Santa Cruz do Sul: Editora Gazeta Santa Cruz, 2013. 140 p.

ASGHARI, S.; ABBAS, S. J.; CHEN, L.; HE, X.; QIN, Y. Micropropagation of Myrica rubra Sieb. and Zucc. using shoot tips and nodal explant. African Journal of Agricultural Research, Nigeria, v. 8, n. 17, p. 1731-1737, 2013.

BANDEIRA, J. M.; TURROW, L. B.; BRAGA, E. J. B.; PETERS, J. A.; BIANCHI, V. J. Enraizamento e aclimatização de ameixeira-japonesa. Revista Brasileira de Fruticultura, Jaboticabal, v. 34, n. 2, p. 597-603, 2012.

BELL, R. L.; REED, B. M. In vitro tissue culture of pear: advances in techniques for micropropagation and germplasm preservation. Acta Horticulturae, Leuven, v. 596, n. 1, p. 412-418, 2002.

BELL, R. L.; SRINIVASAN, C.; LOMBERK, D. Effect of nutrient media on axillary shoot proliferation and preconditioning for adventitious shoot regeneration of pears. In vitro Cellular and Developmental BiologyPlant, Columbia, v. 45, n. 6, p. 708-714, 2009.
BOMMINENI, V. R.; MATHEWS, H.; SAMUEL, S. B.; KRAMER, M.; WAGNER, D. R. A new method for rapid in vitro propagation of apple and pear. HortScience, Alexandria, v. 36, n. 6, p. 1102-1106, 2001.

CARVALHO, A. C. P. P. de; TORRES, A. C.; BRAGA, E. J. B.; LEMOS, E. P. de; SOUZA, F. V. D.; PETERS, J. A.; WILLADINO, L.; CÂMARA, T. R. Glossário de cultura de tecidos de plantas. Plant Cell Culture and Micropropagation, Lavras, v. 7, n. 1, p. 30-60, 2011.

CASANOVA, E.; MOYSSET, L.; TRILLAS, M. I. Effects of Agar concentration and vessel closure on the organogenesis and hyperhydricity of adventitious carnation shoots. Biologia Plantarum, Prague, v. 52, n. 1, p. 1-8, 2008.

CIELNIAK, J. B.; CIELNIAK, J.; FILEK, M.; JANECZKO, A. Rapid production of wheat cell suspension cultures directly from immature embryos. Plant Cell Tissue and Organ Culture, Dordrecht, v. 94, n. 2, p. 139-147, 2008.

D'ONOFRIO, C.; MORINI, S. Development of adventitious shoots from in vitro grown Cydonia oblonga leaves as influenced by different cytokinins and treatment duration. Biologia Plantarum, Prague, v. 49, n. 1, p. 1721, 2005.

DANTAS, A. C. de M.; NESI, A. N.; MACHADO, L. B.; HAERTER, J.; FORTES, G. R. de L. Estabelecimento e multiplicação in vitro de cultivares de Pyrus spp. Revista Brasileira de Agrociência, Pelotas, v. 8, n. 1, p. 19-23, 2002.

DE RIEK, J.; PIQUERAS, A.; DEBERGH, P. C. Sucrose uptake and metabolism in a double layer system for Micropropagation of Rosa multiflora. Plant Cell Tissue and Organ Culture, Dordrecht, v. 47, n. 3, p. 269-278, 1997.

DOBRÁNSZKI, J.; TEIXEIRA DA SILVA, J. A. Micropropagation of apple-a review. Biotechnology Advances, Waterloo, v. 28, n. 4, p. 462-488, 2010.

DRIVER, J. A.; KUNIYUKI, H. In vitro propagation of Paradox walnut rootstock. HortScience, Alexandria, v. 19, n. 4, p. 507-509, 1984.

FACHINELLO, J. C.; PASA, M. S.; SCHMITZ, J. D.; BETEMPS, D. L. Situação e perspectivas da fruticultura de clima temperado no Brasil. Revista Brasileira de Fruticultura, Jaboticabal, v. 33, n. 1, p. 109-120, 2011.

FELDBERG, N. P.; BARBOSA, W.; MAYER, N. A.; SANTOS, F. M. C. Propagação vegetativa de portaenxertos de pereira por estacas semi-lenhosas. Revista Ceres, Viçosa, MG, v. 57, n. 6, p. 810-816, 2010. 
FOOD AND AGRICULTURE ORGANIZATION OF UNITED NATIONS - FAO. Faostat database. Prodstat. 2012. Available at: <http://www.fao.org > . Accessed at: 30 out. 2015.

GIACOBBO, C. L.; FACHINELLO, J. C.; BIANCHI, V. J. Enraizamento de estacas do porta-enxerto de marmeleiro (Cydonia oblonga Mill.) cv. EMC, em diferentes substratos, concentrações de ácido indolbutírico e enxertia de raiz. Ciência e Agrotecnologia, Lavras, v. 31, n. 1, p. 64-70, 2007.

HASSANEN, S. A.; GABR, M. R. In vitro propagation of pear Pyrus betulaefolia rootstock. American-Eurasian Journal of Agricultural and Environmental Science, Dubai, v. 12, n. 4, p. 484-489, 2012.

HAZARIKA, B. N. Morpho-physiological disorders in vitro culture of plants. Scientia Horticulturae, Amsterdam, v. 108, n. 2, p. 105-120, 2006.

JARTOODEH， S. V.; DAVARYNEJAD， GhD.; TEHRANIFAR, A.; KAVEH, H.; BISHEH, H. A. Reducing browning problem in micropropagation of three pear cultivars; Sebri, Shekari and Natanz. Current Opinion in Agriculture, Islamabade, v. 2, n. 1, p. 25-27, 2013.

KADOTA, M.; NIIMI, Y. Effects of cytokinin types and their concentrations on shoot proliferation and hyperhydricity in in vitro pear cultivar shoots. Plant Cell Tissue and Organ Culture, Dordrecht, v. 72, n. 3, p. 261265, 2003.

KARIMPOUR, S.; DAVARYNEJAD, G. H.; BAGHERI, A.; TEHRANIFAR, A. In vitro establishment and clonal propagation of Sebri pear cultivar. Journal of Agricultural Science and Technology, Tehran, v. 15, n. 6, p. 1209-1217, 2013.

KOBAYASHI, T.; NISHIZAWA, N. K. Iron uptake, translocation, and regulation in higher plants. Annual Review of Plant Biology, Palo Alto, v. 63, p. 131-152, 2012.

LLOYD, G.; McCOWN, B. Commercially-feasible micropropagation of mountain laurel (Kalmia latifolia), by use of shoot-tip culture. Proceedings of the International Plant Propagation Society, Seattle, v. 30, n. 1, p. $421-427,1980$.

LUCYSZYN, N.; QUOIRIN, M.; RIBAS, L. L. F.; KOEHLER, H. S.; SIERALOWSKI, M. R. Micropropagation of 'Durondeau' pear in modifiedgelled medium. In vitro Cellular and Developmental Biology-Plant, Columbia, v. 42, n. 3, p. 287-290, 2006.

MACHADO, A. de A.; CONCEIÇÃO, A. R. WinStat: sistema de análise estatística para Windows. Versão 2.0. Pelotas: UFPel/NIA, 2007.
MOK, M. C.; MARTIN, R. C.; MOK, D. W. S. Cytokinins: biosynthesis metabolism and percepcion. In vitro Cellular and Developmental Biology-Plant, Columbia, v. 2, n. 36, p. 102-107, 2000.

MORAES, L. K. A. de; FELISBINO, C.; CRESTANI, L.; SILVA, A. L. da. Estabelecimento e multiplicação in vitro de Pyrus calleryana D-6 em sistema de cultura duplafase. Revista Brasileira de Fruticultura, Jaboticabal, v. 26, n. 3, p. 403-405, 2004.

MURASHIGE, T.; SKOOG, F. A revised medium for rapid growth and bio assays with tobacco tissue cultures. Physiologia Plantarum, Copenhagem, v. 15, n. 3, p. 473479, 1962.

NAKASU, B. H.; LEITE, D. L. Pirus 9: seleção de pereira para o Sul do Brasil. Hortisul, Pelotas, v. 2, n. 3, p. 19-20, 1992.

OLIVEIRA, R. P.; SILVEIRA, D. G.; SILVA, S. O. Concentração de BAP e a eficiência de microcpropagação de bananeira tetraplóide (grupo AAAB). Scientia Agricola, São Paulo, v. 58, n. 1, p. 73-78, 2001.

PATI, P. K.; RATH, S. P.; SHARMA, M.; SOOD, A.; AHUJA, P. S. In vitro propagation of rose: a review. Biotechnology Advances, Waterloo, v. 24, n. 1, p. 94-114, 2006.

QUOIRIN, M.; LEPOIVRE, P. Etude de milieux adaptes aux cultures in vitro de Prunus. Acta Horticulturae, Leuven, v. 78, n. 1, p. 437-442, 1977.

RADMANN, E. B.; BIANCHI, V. J.; FACHINELLO, J. C.; FERREIRA, L. V.; OLIVEIRA, R. P. In vitro multiplication of 'Flordaguard' rootstock: cytokinin source and concentration effects, explants orientation and period of permanence in the cultive medium. Brazilian Archives of Biology and Technology, Curitiba, v. 54, n. 1, p. 25-34, 2011.

RADMANN, E. B.; BIANCHI, V. J.; SOUZA, T. M.; FACHINELLO, J. C.; OLIVEIRA, R. P. Influência da composição do meio de cultivo e do tipo de explante na micropropagação do portaenxerto de Prunus sp. 'GxN9'. Scientia Agraria, Curitiba, v. 10, n. 2, p. 095-101, 2009.

RAMAGE, C. M.; WILLIAMS, R. R. Mineral nutrition and plant morphogenesis. In vitro Cellular and Developmental Biology-Plant, Columbia, v. 38, n. 2, p. 116-124, 2002.

RODRIGUEZ, R.; DÍAZ-SALA, C.; CUOZZO, L.; ANCORA, G. Pear in vitro propagation using a Doublephase culture system. HortScience, Alexandria, v. 26, n. 1, p. 62-64, 1991. 
RUZIC, D.; VUJOVIC, T.; MILENKOVIC, S.; CEROVIC, R.; MILETIC, R. The infuence of Imidazole fungicides on multiplication in vitro of pyrodwarf pear rootstock. Australian Journal of Crop Science, Brisbane, v. 1, n. 2, p. 63-68, 2008.

SCHMIDT, W. Iron solutions: acquisition strategies and signaling pathways in plants. Trends in Plant Science, London, v. 8, n. 4, p. 188-193, 2003.

SILVA, I. M. C.; PETERS, J. A.; BRAGA, E. J. B.; BIANCHI, J. V. Resposta diferencial ao uso do thidiazuron na regeneração in vitro de marmeleiros, cvs. Adams e MC. Revista Brasileira de Agrociência, Pelotas, v. 17, n. 3-4, p. 375-382, 2011.

SILVA, L. C.; SCHUCH, M. W.; SOUZA, J. A.; ERIG, A. C.; ANTUNES, L. E. C. Meio nutritivo, reguladores de crescimento e frio no estabelecimento in vitro de mirtilo (Vaccinium ashei Reade) cv. 'Delite'. Revista Brasileira de Agrociência, Pelotas, v. 12, n. 4, p. 405-408, 2006.

VUJOVIC, T.; RUZIC, Dj.; CEROVIC, R. In vitro shoot multiplication as influenced by repeated subculturing of shoots of contemporary fruit rootstocks. Horticultural Science, Prague, v. 39, n. 3, p. 101-107, 2012.
WOOD, G. A. Viruses and phytoplasma in European pear trees in New Zealand and the role of these pathogens in the compatibility of pear with quince rootstocks. New Zealand Journal of Crop and Horticultural Science, Wellington, v. 25, n. 4, p. 333-340, 1997.

XU, G.; FAN, X.; MILLER, A. J. Plant nitrogen assimilation and use efficiency. Annual Review of Plant Biology, Palo Alto, v. 63, n. 1, p. 153-182, 2012.

YASEEN, M.; AHMAD, T.; ABBASI, N. A.; HAFIZ, I. A. Assessment of apple rootstocks M9 and M26 for in vitro rooting potential using different carbon sources. Pakistan Journal Botany, Karachi, v. 41, n. 2, p. 769-781, 2009a.

In vitro shoot proliferation competence of apple rootstocks M9 and M26 on different carbon sources. Pakistan Journal Botany, Karachi, v. 44, n. 4, p. 17811795, 2009b. 
